Punkty Ministerialne z 2019 - aktualny rok 40 punktów. Zalącznik do komunikatu Ministra Edukacji i Nauki z dnia 1 grudnia 2021 r. Lp. 32343. Posiada Unikatowy Identyfikator Czasopisma: 201159. Przypisane dyscypliny naukowe:Nauki o kulturze fizycznej (Dziedzina nauk medycznych i nauk o zdrowiu); Nauki o zdrowiu (Dziedzina nauk medycznych i nauk o zdrowiu).

\title{
Autyzm jako wyzwanie w wymiarze medycznym, diagnostyczny i terapeutyczny
}

\section{Autism as a challenge in the medical, diagnostic and therapeutic dimension}

\author{
Natalia Jach-Salamon
}

E-mail address: natalii.jach@gmail.com

ORCID iD: https://orcid.org/0000-0003-1231-8086

Affiliation: Maria Curie-Sklodowska University, Lublin, Poland

\section{Streszczenie}

Wprowadzenie i cel pracy: Autyzm stanowi całościowe, rozległe zaburzenie rozwoju. Wpływa na przebieg różnych procesów i znacznie ogranicza osobom nim dotkniętym, możliwość samodzielnego, niezależnego od opieki innych ludzi, życia. Zgodnie ze współczesną wiedzą autyzm zaliczany jest do problemów o podłożu neurobiologicznym. Budzi on duże zainteresowanie badaczy, pozostając wciąż stosunkowo słabo poznanym [24]. Celem pracy był przegląd wiedzy w obszarze wieloaspektowego podłoża autyzmu oraz diagnostycznego i terapeutycznego charakteru zaburzeń autystycznych.

Opis stanu wiedzy: Obecnie autyzm traktowany jest jako zaburzenie neurorozwojowe, którego objawy ujawniają się zwykle przed osiągnięciem przez dziecko wieku trzech lat. Osoby dotknięte tym zaburzeniem przejawiają deficyty w zakresie interakcji społecznych, komunikacji werbalnej i niewerbalnej, jak również prezentują zaburzone (ograniczone lub stereotypowe) wzorce zachowania. Autyzm jako schorzenie niejednorodne, może również współistnieć z różnego rodzaju zaburzeniami m.in. upośledzeniem umysłowym, padaczką, zaburzeniami lękowymi czy nastroju $[1,35]$.

Podsumowanie: Prognozy dotyczące rozwoju, stopnia przystosowania się i wyjścia z autyzmu nie są optymistyczne. Mimo postępów w diagnozowaniu, terapii i edukacji sukces w postaci pełnego wyleczenia jest wciąż „,rzadki”. Natomiast istotny jest fakt, że sytuacja osób dotkniętych tych zaburzeniem rozwoju stopniowo poprawia się, dzięki coraz lepszym programom edukacyjnym oraz terapeutycznym, jak również dzięki podejmowanym inicjatywom na rzecz zwiększania możliwości uczestniczenia tych osób w życiu społecznym. 
Słowa kluczowe: autyzm, całościowe zaburzenia rozwoju, diagnoza, terapia

\begin{abstract}
Introduction and purpose of the work: Autism is a holistic, extensive development disorder. It influences the course of various processes and significantly reduces the possibility of an independent life, independent of other people's care, for those affected by it. According to modern knowledge, autism is classified as a neurobiological problem. It arouses great interest among researchers, while still being relatively poorly understood [24]. The aim of the study was to review knowledge in the area of the multifaceted basis of autism and the diagnostic and therapeutic nature of autistic disorders.

Description of the state of knowledge: Currently, autism is treated as a neurodevelopmental disorder, the symptoms of which usually appear before the child reaches the age of three. People affected by this disorder exhibit deficits in social interactions, verbal and non-verbal communication, as well as display disturbed (limited or stereotypical) behavior patterns. Autism as a heterogeneous disease may also coexist with various types of disorders, including mental retardation, epilepsy, anxiety or mood disorders $[1,35]$.

Summary: The prognosis for development, adaptation and recovery from autism is not optimistic. Despite advances in diagnosis, therapy, and education, success to a full cure is still "rare". On the other hand, it is important that the situation of people affected by these development disorders is gradually improving, thanks to better and better educational and therapeutic programs, as well as thanks to the initiatives taken to increase the opportunities for these people to participate in social life.
\end{abstract}

Keywords: autism, pervasive developmental disorders, diagnosis, therapy

\title{
Wprowadzenie
}

Autyzm traktowany jest jako zaburzenie neurorozwojowe, którego objawy ujawniają się zwykle przed osiągnięciem przez dziecko wieku trzech lat. Osoby dotknięte tym zaburzeniem przejawiają deficyty w zakresie interakcji społecznych, komunikacji werbalnej i niewerbalnej, jak również prezentują zaburzone (ograniczone lub stereotypowe) wzorce zachowania. Autyzm jako schorzenie niejednorodne, może również współistnieć z różnego rodzaju zaburzeniami m.in. upośledzeniem umysłowym, padaczką, zaburzeniami lękowymi czy nastroju $[1,35]$. Zgodnie ze współczesną wiedzą autyzm zaliczany jest do problemów o podłożu neurobiologicznym. Budzi on duże zainteresowanie badaczy, pozostając wciąż stosunkowo słabo poznanym [24].

Pionierami w zakresie autyzmu dziecięcego byli Kanner i Asperger, którzy w swych publikacjach zawarli szczegółowe opisy przypadków i zaprezentowali pierwsze próby teoretycznego wyjaśnienia tego zaburzenia. Obaj uważali, że tego rodzaju specyficzne problemy wynikają z podstawowej biologicznej anomalii, występującej od urodzenia [10]. Jednakże termin ,autyzm” do współczesnej literatury medycznej po raz pierwszy wprowadził amerykański psychiatra Kanner w 1943 roku, który zajął się w swojej pracy naukowej problematyką zaburzeń autystycznych. Na podstawie jedenastu przypadków opracował podstawy zespołu, który nazwał ,wczesnym autyzmem dziecięcym” (Zabłocki, 2002). Była to pierwsza próba syntezy $\mathrm{w}$ dziedzinie zaburzeń psychicznych u małego dziecka, którą przedstawił w artykule „Zaburzenia autystyczne kontaktu afektywnego" (Autistic disturbances of affective contact). Kanner zwrócił uwagę na następujące objawy autystycznego zaburzenia: niezdolność do interakcji społecznych, stereotypowe, powtarzające się czynności, brak mowy lub mowa niekomunikatywna, dążenie do niezmienności otoczenia, 
brak wyobraźni, opóźnienie w rozwoju języka, mylenie zaimków, echolalia, łatwość mechanicznego zapamiętywania [37].

Termin „autystyczny” i ,autyzm” wywodzi się z greckiego słowa „autós” oznaczającego ,sam”. Dziś są one używane prawie wyłącznie w odniesieniu do zaburzenia rozwojowego, które nazywamy autyzmem. Określenia, których używano kiedyś, a więc „autyzm wczesnodziecięcy” (early infant ile autism) i ,autyzm dziecięcy” (childhood autism), wyszły z użycia, ponieważ sugerowały jakiś kontrast w stosunku do „dorosłego autyzmu”, a tym samym wprowadzały w błąd, że z autyzmu można wyrosnąć [10]. Autyzm jako jednostka chorobowa został opisany już ponad 70 lat temu. Do czasów obecnych zmienił się sposób definiowania tego zaburzenia, a także kryteria jego rozpoznawania oraz metody terapeutyczne $[24]$.

\section{Cel pracy}

Celem pracy był przegląd wiedzy w obszarze wieloaspektowego podłoża autyzmu oraz diagnostycznego i terapeutycznego charakteru zaburzeń autystycznych.

\section{Wielowymiarowy charakter podłoża autyzmu}

„Pytanie o przyczyny autyzmu pozostanie przedmiotem burzliwych rozważań jeszcze przez pewien czas. Zastanawiając się nad nimi, musimy myśleć o długim łańcuchu przyczynowo-skutkowym i o jego poszczególnych ogniwach. Mówiąc obrazowo, istnieje jakieś zagrożenie powodujące zniszczenie, które z kolei powoduje uszkodzenie. Zagrożenia mogą być różne: od wadliwych genów, przez nieprawidłowości chromosomalne, choroby metaboliczne, czynniki wirusowe, brak tolerancji immunologicznej, po niedotlenienie spowodowane problemami okołoporodowymi. Zakładamy, że każde z tych zagrożeń może spowodować zniszczenie w rozwoju układu nerwowego. To z kolei może doprowadzić do trwałych uszkodzeń $\mathrm{w}$ konkretnym obszarze mózgu, związanym $\mathrm{z}$ wyższymi procesami umysłowymi. Uszkodzenie może być łagodne albo poważne, ale zawsze oznacza, że w krytycznym momencie zatrzymuje się rozwój jednego lub więcej kluczowych schematów. Z punktu widzenia teorii naukowej tylko wtedy może wystąpić autyzm” [10].

Czynniki genetyczne w etiologii autyzmu

Obecnie autyzm dziecięcy jest uznawany za zaburzenie uwarunkowane genetycznie, a jego odziedziczalność - ta część zmienności danej cechy, która w kolejnych pokoleniach zależna jest od czynników dziedzicznych - została obliczona na około 90\%. Natomiast stwierdzono, że żaden $\mathrm{z}$ genów nie jest specyficznie związany $\mathrm{z}$ wystąpieniem autyzm. Potwierdzeniem dziedzicznego charakteru tego zaburzenia są poniższe dane:

- ryzyko wystąpienia autyzmu u rodzeństwa autysty wynosi od 2 do 8\% [14],

- badania nad bliźniętami wykazały, że wśród bliźniąt jednojajowych (monozygotycznych) zgodność występowania autyzmu wynosiła 60-95\%, natomiast wśród dwujajowych (dizygotycznych) - około 5-8\% [25],

- analizy występowania u bliźniąt objawów szerszego spektrum autystycznego tj. zaburzenia komunikacji oraz zaburzenia funkcjonowania społecznego) wykazał jeszcze większa zgodność, która u bliźniąt jednojajowych wynosi 92\% a u dwujajowych $10 \%$ [14],

- badania z udziałem krewnych osób autystycznych wskazują na fakt, że pewne cechy autyzmu, takiej jak wycofanie, brak bliskich relacji, sztywność mogą występować u członków ich rodzin (np. rodziców) [10],

- Szacuje się, że deficyty (np. trudności w funkcjonowaniu podczas interakcji, obejmujące zwłaszcza ograniczoną zdolność do społecznej naprzemienności) spotykane w przypadku zaburzeń należących do autystycznego spektrum występują u co najmniej $10 \%$ braci i sióstr autystycznych dzieci [18].

Obecny stan wiedzy na temat genetycznych przyczyn autyzmu pozwala na sformułowanie wniosku, który mówi o tym, że nie jest dziedziczone zaburzenie jako takie, co 
raczej predyspozycja do pewnego sposobu funkcjonowania społecznego oraz trudności w zakresie komunikacji z innymi ludzi. Wynika $\mathrm{z}$ tego, że predyspozycje genetyczne moga odgrywać rolę na przykład $\mathrm{w}$ ograniczonych kontaktach $\mathrm{z}$ innymi ludźmi, preferowaniu samotności, zaburzeniach i opóźnieniach w rozwoju mowy, czy doświadczaniu lęku w sytuacjach społecznych i przejawianiu pewnej sztywności w zakresie różnych zachowań [2]. Częste występowanie wyżej wymienionych trudności u osób spokrewnionych z autystycznym dzieckiem, stało się przyczyną opisania tzw. szerszego fenotypu autyzmu (BAP-Bronder autism phenotype) [9]. Obecnie istnieje sześć cech charakterystycznych dla szerokiego fenotypu autyzmu, którymi są:

- trudności w przetwarzaniu informacji dotyczących twarzy - rozpoznawanie emocji, rozpoznawanie twarzy,

- obniżona zdolność do tworzenia więzi społecznych lub wrażliwość na wzmocnienia społeczne (np. dezaprobatę lub pochwałę),

- słabe umiejętności naśladowania ruchów,

- gorsza pamięć bodźców społecznych,

- trudności w zakresie planowania, kontroli wykonania czynności oraz płynności działania (oraz elastycznego dostosowywania go do zewnętrznych okoliczności),

- $\quad$ słabsze zdolności językowe, zwłaszcza fonologiczne [25].

Należy stwierdzić, że istnieje duża różnica między szerokim fenotypem autyzm

a samym autyzmem i nie należy tych pojęć utożsamiać, czy nawet zakładać silny związek między nimi. Może on polegać na genetycznym uwarunkowaniu pewnych cech, które u członków rodziny autystycznego dziecka (rodziców lub rodzeństwa) stanowią jedynie specyficzny „styl” ich funkcjonowania, a u samego dziecka są bardziej nasilone i uczestniczą $\mathrm{w}$ powstaniu autyzmu. Wniosek $\mathrm{z}$ tego taki, że geny być może zwiększają podatność na wystąpienie zaburzenia, ale nie przesądzają o nim w stu procentach [25].

Natomiast badania genomu osób autystycznych wykazały, że istnieje co najmniej 15 genów, które mogą być związane $\mathrm{z}$ wystąpieniem tego zaburzenia i że geny związane $\mathrm{z}$ jego etiologią mogą być położone prawie na wszystkich chromosomach. Jednakże najwięcej zgodnych wyników badań dotyczy genów położonych na chromosomie 7, 2, 15 i 17 [10, 14, $15,24]$. Analizuje się wpływ poszczególnych genów na rozwój kory mózgowej, dróg nerwowych, budowę móżdżku, rozwój połączeń synaptycznych, migrację neuronów w obrębie mózgu w toku rozwoju płodowego oraz neuroprzekaźnictwo. Istnieją wnioski, co do związków między zaburzeniami rozwoju mowy a mutacjami na chromosomie 7 oraz pomiędzy stereotypiami ruchowymi a zmianami na chromosomie 15 [14].

Kolejną hipotezą dotyczącą przyczyn autyzmu jest hipoteza stresu prenatalnego. Zespół naukowców powiązał pewne przypuszczenia, że nieprawidłowości w budowie mózgu autystycznych osób powstają przed 30.-32. tygodniem ciąży z zaobserwowanym przez nich faktem doświadczania przez matki dzieci $\mathrm{z}$ autyzmem dużego stresu. Okazało się, że doświadczany przez nie stres był częstszy u nich niż u matek dzieci z zespołem Downa i dzieci rozwijających się prawidłowo oraz większy w okresie miedzy 21. a 32. tygodniem ciąży i mógł przyczynić się do zaburzeń w rozwoju płodu [5].

Do uwarunkowanych genetycznie zaburzeń związanych z ryzykiem wystąpienia autyzmu zalicza się: fenyloketonurię; stwardnienie guzowate; zespół kruchego chromosomu X; zespół Angelmana; nerwiakowłókniakowatość (choroba Recklinhausena); zespół WilliegoPradera; dystrofię mięśniową Duhenne'a [14]; stany chorobowe, np. Zespół Moebiusa oraz inne zespoły anomalii wrodzonych [4]. Podsumowując można stwierdzić, że autyzm może być spowodowany pewnymi stanami genetycznymi, które jednak nie są odpowiedzialne za wszystkie przypadki autyzmu.

Czynniki działające w okresie ciąży i porodu 
Jedna $\mathrm{z}$ teorii mówi, że pewne toksyny i wirusy, oddziałujące na płód w interakcji z jego genami, mogą doprowadzić do typowych dla autyzmu nieprawidłowości w rozwoju mózgu [13]. Problemy matki w czasie ciąży i porodu są częstsze u dzieci z autyzmem i wiążą się z ryzykiem wystąpienia tego zaburzenia. Można wymienić następujące sytuacje „ryzyka” ciąży i porodu:

- wiek rodziców (matki - w wieku 35 i więcej miały w jednym z badań nawet 3,4 razy wyższe ryzyko urodzenia autystycznego dziecka w porównaniu $\mathrm{z}$ kobietami młodszymi; ojcowie - każde dodatkowe 10 lat życia ojca oznacza dwukrotny wzrost ryzyka wystąpienia u dziecka objawów z autystycznego spektrum [14],

- infekcje wewnątrzłonowe, np. przebycie przez matkę różyczki w czasie ciąży,

- przedwczesny poród i dystrofia wewnątrzłonowa (zbyt mała waga płodu w stosunku do wieku ciążowego), zamartwica (dzieci otrzymujące poniżej 7 punktów w skali Apgar),

- poronienia i zagrożenie poronieniem, niedotlenienie płodu, cesarskie cięcie, zatrucie ciążowe z nadciśnieniem (gestora),

- codzienne palenie papierosów przez matkę podczas ciąży,

- niedobór beta-hydroksylazy dopaminy (delecja genu na chromosomie 19) w organizmie matki, który prowadzi do wzrostu poziomu dopaminy i obniżenia noradrenaliny we krwi matki w czasie ciąży, co może prowadzić do zaburzeń rozwoju neuronów i receptorów amin katecholowych u płodu [14],

- kolejność urodzeń - pierwsze, czwarte, lub urodzone jako ostatnie dziecko są obciążone większym ryzykiem,

- stosowanie leków w czasie trwania ciąży i narażenie płodu na kontakt z metalami ciężkimi,

- obecność smółki (pierwsze stolce noworodka) w płynie owodniowym podczas porodu,

- występujące krwawienie pomiędzy czwartym, a ósmym miesiącem ciąży,

- niezgodność czynnika Rh pomiędzy grupami krwi matki i dziecka

- niska waga urodzeniowa oraz wcześniactwo [4, 25].

Wyżej wymienione komplikacje występujące w okresie ciąży i porodu są powiązane $\mathrm{z}$ autyzmem, jednakże nie są prawdopodobnie wystarczającą przyczyną powodującą autyzm. Natomiast mogą one działać w połączeniu z czynnikami genetycznymi lub innymi lub też jedynie wskazywać na obecność już istniejących nieprawidłowości u przychodzącego na świat dziecka [4].

Oprócz czynników genetycznych oraz komplikacji w czasie ciąży i porodu, również infekcje, które powodują uszkodzenie mózgu podczas ciąży, czy w dzieciństwie są związane z autyzmem. Można wśród nich wymienić: różyczkę, wirus cytomegalii (CMV), czy opryszczkowe zapalenie mózgu [4].

Czynniki neurologiczne, neurochemiczne i neuroanatomiczne w genezie autyzmu

Współczesne badania $\mathrm{z}$ lata 90. jednoznacznie potwierdziły istnienie $\mathrm{w}$ centralnym

układzie nerwowym autystów zmian neurologicznych, takich jak:

- dysfunkcja okoruchowa [6],

- anormalny wzór EEG,

- nieprawidłowe funkcjonowanie układu przedsionkowego,

- zaburzenia kontroli motorycznej [20, 24].

Najczęściej występujące zaburzenia neurologiczne u osób cierpiących na autyzm to: zaburzenia w rytmie okołodobowym, nieprawidłowy wzorzec ruchowy ujawniający się podczas pełzania i chodzenia, jak również zaburzenia zawiązane $\mathrm{z}$ dominacją półkulową. $\mathrm{U}$ innych autystów deficyty te ujawniały się w zakresie postawy ciała, koordynacji ruchów lub apraksji w obrębie twarzy. Zaś u około jednej czwartej dzieci z autyzmem stwierdza się 
hipotonię, natomiast bardzo rzadko występuje spastyczność (u mniej niż 5\%). Natomiast padaczka występuje u około $20 \%$ do $32 \%$, natomiast nieprawidłowości w zapisie EEG często pochodzą z okolic płatów skroniowych i stwierdza się je u około 40-65\% autystycznych dzieci [22].

Badania współczesnych naukowców dotyczące zmian neurochemicznych zachodzących w mózgach osób autystycznych dostarczyły wielu analiz, które wskazują na poniższe nieprawidłowości:

- podwyższony lub bardzo obniżony poziom serotoniny we krwi i płynie mózgowo rdzeniowym,

- zwiększony poziom beta-endorfin i peptydów endogennych o działaniu opiatu [27],

- obniżony poziom oksytocyny,

- podwyższony poziom $\mathrm{T}_{3} \mathrm{i} \mathrm{T}_{4}$,

- nieprawidłowości w poziomie opioidów neuroanatomicznych - np. zmniejszenie objętości płata ciemieniowego i tylnej części ciała modzelowatego) [20],

- nieprawidłowe funkcjonowanie systemu monoaminergicznego,

- nie modulowany wzrost reakcji hormonalnej w odpowiedzi na indukowaną insuliną hiperglikemię [6].

Współczesne badania anglojęzycznych uczonych $[6,23]$ odkryły związek autyzmu z wysokim poziomem opioidów (endorfin), które są neuroregulatorami w systemie nerwowym człowieka i mają wpływ na uwalnianie niektórych neuroprzekaźników (np. dopaminy, serotoniny, epinefryny). Odkryto również związek pomiędzy autyzmem a różnymi alergenami (w tym pokarmowymi i wziewnymi), na które uczulony jest organizm dziecka.

U osób cierpiących na autyzm stwierdzono nieprawidłowe stężenie beta-endorfiny w surowicy krwi. Z uwagi na fakt, że endogenne opioidy wywierają wpływ na powstawanie przywiązania między dzieckiem a matką (wykazany w badaniach nad zwierzętami), sformułowano hipotezę, że nadmierna aktywność tego przekaźnika może mieć związek z zaburzeniami przywiązania oraz genezą i utrzymywaniem się objawów autystycznych u ludzi. Ponadto podwyższony poziom beta-endorfiny u osób z ciężkimi objawami autyzmu może być również związany $\mathrm{z}$ wygórowaną reakcją organizmu na stres - jej podwyższone stężenie zaobserwowano również u autystycznych dzieci z nasiloną autoagresją. Wyniki badań mówią o znacznie niższym stężeniu oksytocyny (neuropeptydu, który wpływa na powstawanie relacji przywiązaniowej oraz odpowiada za zdolności afiliacyjne) u osób autystycznych w porównaniu z osobami zdrowymi [14]. Oksytocyna odpowiedzialna jest za rozpoznawanie myśli i emocji innych ludzi (np. po mimice, barwie głosu, motoryce, współruchach), ich nastrojów, stanów emocjonalnych oraz odgadywania ich ukrytych pragnień i zamiarów; zwiększa również przenikliwość obserwacji innych osób, a także pamięć naszych poprzednich kontaktów z nimi - jej niedobór osłabia wymienione predyspozycje, których „niedostatek” jest widoczny w funkcjonowaniu autystycznych osób [20].

Autyzm jest konsekwencją nieprawidłowego funkcjonowania mózgu. Wyniki badań neuroobrazowania ośrodkowego układu nerwowego (z użyciem np. TK - tomografii komputerowej czy MRI - rezonansu magnetycznego) wskazują na związki autyzmu z anomaliami budowy i funkcjonowania określonych struktur mózgowych:

- kory przedczołowej,

- części skroniowo-potylicznej mózgu,

- tzw. mózgu społecznego - to jest ciała migdałowatego i płatów czołowych,

- wielkości i masy mózgu,

- móżdżku,

- układu limbicznego: jądra migdałowatego oraz hipokampa,

- nieprawidłowości w budowie dendrytów [13, 14, 25, 27], 
- móżdżku, a dokładniej płacików robaczkowatych VI-VIII [4].

Wśród obszarów mózgu, w których stwierdza się uszkodzenia u osób z autyzmem wymienia się m.in.: pień mózgu, płaty skroniowe i czołowe, móżdżek, ciało migdałowate, hipokamp, przegroda i kora oczodołowa [15]. Natomiast Waterhouse, Fein i Modahl znalazły 16 różnych lokalizacji uszkodzeń mózgu, które dowiedziono w różnych badaniach [23].

Badania pośmiertne dzieci i osób dorosłych wykazały nieprawidłowości w wielu obszarach mózgu, zazwyczaj albo w płatach czołowych, albo w układzie limbicznym, albo w pinu mózgu (który jest hipoplastycznie skrócony) i w czwartej komorze mózgu, albo też w móżdżku [4].

Rysunek 1 stanowi wizualną prezentację głównych obszarów mózgu, które są powiązane z trzema głównymi deficytami występującymi w autyzmie [1]. 

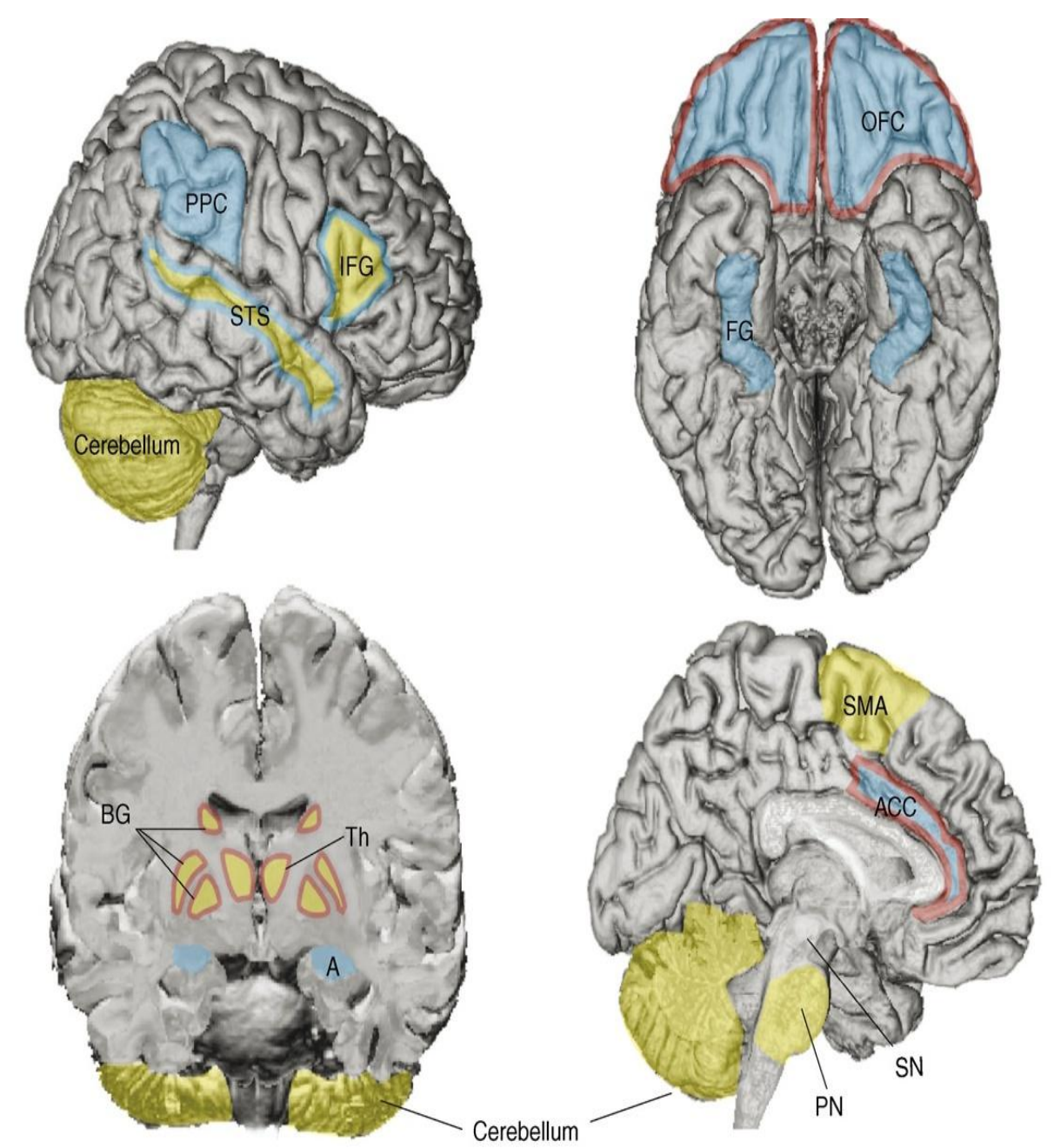

\section{DEFICYTY W ZAKRESIE INTERAKCJI SPOLECZNYCH}

Kora oczodołowa-czołowa (OFCOrbitofrontal cortex)

Przednia kora zakrętu obręczy (ACC-Anterior cingulate cortex)

Zakręt wrzecionowaty (FGFusiform gyrus)

Górna bruzda skroniowa (STSSuperior temporal sulcus) Ciało migdałowate (A-Amygdala mirror neuron regions)

Zakręt czołowy dolny (IFGInferior frontal gyrus) Tylnia kora ciemieniowa (PPCPosterior parietal cortex)

\section{ZABURZENIA KOMUNIKACJI WERBALNEJ I NIEWERBALNEJ}

Zakręt czołowy dolny (IFGInferior frontal gyrus); ośrodek Broki (Broca'a area)

Górna bruzda skroniowa

(STS-Superior temporal sulcus)

Dodatkowy obszar ruchowy (SMA-Supplementary motor area)

Jądra podstawy (BG-Basal ganglia)

Substancja czarna (SN-

Substantia nigra)

Wzgórze (Th-Thalamus)

Jądro mostu (PN-Pontine nuclei cerebellum)
ZABURZONE (OGRANICZONE LUB STEREOTYPOWE) WZORCE ZACHOWANIA

Kora oczodołowa-czołowa

(OFC-Orbitofrontal cortex)

Przednia kora zakrętu obręczy

(ACC-Anterior cingulate cortex)

Jądra podstawy (BG-Basal ganglia)

Wzgórze (Th-Thalamus)

Zastosowanie technik neuroobrazowania in vivo $\mathrm{w}$ badaniach dzieci $\mathrm{z}$ grupy ryzyka pozwala stwierdzić, że mają one w momencie narodzenia mózg prawidłowej wielkości. Od około czwartego miesiąca życia zaznaczają się różnice w tempie wzrostu jego masy i 
stwierdza się, że mózg tych dzieci rośnie znacznie szybciej niż u ich prawidłowo rozwijających się rówieśników. Nietypowa wielkość dotyczy głównie móżdżku i istoty białej mózgu, jednakże w świetle badań nie można jednoznacznie stwierdzić, które struktury mózgowe rozwijają się nieprawidłowo. Pojawiły się również informacje sugerujące, że nieprawidłowa dynamika wzrostu czaszki u rodzeństwa dzieci z autyzmem może być jednym $\mathrm{z}$ istotnych sygnałów ostrzegających o nieprawidłowym rozwoju [8].

W kilku badaniach stwierdzono mniejszą liczbę komórek Purkinjego w móżdżku u osób z autyzmem, która może być spowodowana przez wiele różnych czynników, np. wada chromosomu 15, mutacja jednego $\mathrm{z}$ genów, czy działanie leku przeciw drgawkowego. Badania wskazują na zmniejszoną liczbę połączeń nerwowych pomiędzy różnymi ośrodkami mózgu, w tym nieprawidłowy rozwój ciała modzelowatego oraz połączeń pomiędzy korą mózgową, strukturami podkorowymi i móżdżkiem. W badaniach zaobserwowano również zwiększoną objętość całego mózgu, móżdżku i jądra ogoniastego oraz zmniejszoną objętość ciała modzelowatego i migdałowatego. Stwierdzono także przetrwałe z okresu płodowego połączenia pomiędzy jądrami móżdżku, jak również nadmierną gęstość komórek nerwowych w ciałach migdałowatych i hipokampie. Badania dowodzą, że powiększenie ciała migdałowatego jest nieproporcjonalnie powiększone w stosunku do całkowitej objętości mózgu u małych dzieci. Stwierdzono również, że mężczyźni i kobiety różnią się w poziomie powiększenia tej struktury mózgu, co wpływa na różnorodność stopnia upośledzenia umiejętności społecznych i komunikacji miedzy nimi. Dane te będą miały istotny wpływ na określenie neuronalnego podłoża fenotypu mężczyzn i kobiet $\mathrm{z}$ autyzmem, które staną się kluczowe w kolejnych poszukiwaniach przyczyn tego zaburzenia [6, 14, 31].

Podsumowując doniesienia z badań i wnioski dotyczące etiologii autyzmu należy stwierdzić, że to zaburzenie ma wielo płaszczyznową strukturę i nadal nie poznaliśmy jedynej i „prawdziwej” jego przyczyny. Wiele różnych badań prowadzonych nad genezą autyzm prezentowało wnioski, w których wiązano występowanie autyzmu z wieloma czynnikami tj., zatruciem rtęcią, wadami chromosomów (zwłaszcza 15, 17), warunkami życia dziecka i rodzicielskimi postawami i relacjami z dzieckiem, wadami ośrodkowego układu nerwowego w zakresie takich struktur, jak m.in. kora czołowa, ciało migdałowate, hipokamp, płat skroniowym, czy objętości substancji szarej mózgu, poziomie serotoniny, braku neuronów lustrzanych i globalnym obniżeniem funkcjonowania mózgu osób autystycznych. W badaniach tych brano pod uwagę różne czynniki ogólnoustrojowe, wzrost i zmiany hormonalne i zaburzenia elektrolitowe, zwłaszcza z udziałem Ca2 +, czy stres oksydacyjny i wysoki poziom testosteronu [15].

\section{Diagnoza autyzmu dziecięcego}

Autyzm jest zdefiniowanym zaburzeniem rozwoju, pomimo wielu niewiadomych, które w sobie kryje. Mimo, że posiada jasno określone kryteria diagnostyczne, to wciąż jednak poważne problemy stwarza odróżnianie go od innych zaburzeń rozwoju takich jak: zespół Aspergera; opóźnienie rozwoju/ upośledzenie umysłowe; zaburzenie lękowe (np. fobia społeczna); zespół stresu pourazowego; zaburzenia obsesyjno-kompulsyjne; ADHD; zaburzenia rozwoju mowy i języka; specyficzne zaburzenia rozwoju umiejętności szkolnych; głuchota; zaburzenia integracji sensorycznej [25].

$\mathrm{Z}$ autyzmem współwystępować mogą różne problemy medyczne, dlatego też lekarz badający stan zdrowia dziecka, powinien sprawdzić, czy poza autyzmem dziecko nie ma: epilepsji, alergii, celiakii i zaburzeń trawienia, dysfunkcji nerek i wątroby, uczulenia na leki, dysfunkcji układu odpornościowego, zaburzeń metabolicznych [25].

Wybrane metody i narzędzia diagnostyczne

Najczęściej stosowanymi procedurami służącymi diagnozie autyzmu są:

$>$ Wywiad z rodzicami dziecka 
Metod ta ma szczególne znacznie w procesie diagnozy. Rozpoznanie autyzmu u dziecka, opiera się na dokładnej analizie przebiegu jego rozwoju od pierwszych dni życia oraz na dokładnej analizie funkcjonowania dziecka w różnych sytuacjach. Bardzo ważne są informacje uzyskane od rodziców na temat historii medycznej dziecka (np. przebieg ciąży i porodu), rozwoju psychoruchowego, codziennej aktywności i zachowania się go w różnych okolicznościach, a także sytuacji rodzinnej (np. zaburzenia rozwoju, choroby dziedziczne czy genetyczne występujące u członków rodziny, przebieg interakcji, klimat emocjonalny, oczekiwania wobec dziecka). To od rodziców można dowiedzieć się wielu informacji, które są niedostępne podczas badania innymi metodami. Dotyczy to choćby sposobów komunikowania stosowanych przez dziecko, sposobu wyrażania przez nie potrzeb i uczuć. To W najbliższej rodzinie dziecka można znaleźć albumy, filmy kręcone podczas urodzin lub rodzinnych uroczystości, które są bezcenne podczas opisu zachowania dziecka w różnych sytuacja na przestrzeni lat. Wywiad prowadzony pod kątem autyzmu ma zazwyczaj strukturę odpowiadającą kryteriom diagnostycznym tego zaburzenia rozwoju zawartym w ICD-10 lub DSM-IV. Umożliwia to przyjęcie pewnego schematu, zgodnie z którym pytania dotyczą przede wszystkim trzech obszarów funkcjonowania: naprzemiennych interakcji społecznych, języka i komunikacji oraz ograniczonych, sztywnych wzorców zachowania, aktywności i zainteresowań. Niektórzy diagności stosują arkusze zbiorcze, zawierające zestawienie danych o symptomach występujących u badanego dziecka - diagnosta zaznacza w tabeli, czy dane kryterium jest spełnione lub też, w jakim stopniu dany problem się ujawnia.

$>$ Skale obserwacji zachowań

Bezpośrednia obserwacja zachowania dziecka jest równie ważnym elementem diagnozy i źródłem cennych informacji, co wywiad. Aby zebrać jak najpełniejsze dane o dziecku należy przeprowadzić kilka sesji obserwacyjnych w różnych warunkach, min.: w środowisku naturalnym - w domu; w grupie rówieśniczej (np. w przedszkolu); w nowym otoczeniu (np. pod kątem zainteresowania dziecka przedmiotami znajdującymi się tam); w relacji z opiekunami; czy w sytuacji, gdy nieznana dziecku osoba chce nawiązać $\mathrm{z}$ nim kontakt [24].

W celu uporządkowania danych obserwacyjnych można wykorzystać specjalnie opracowane narzędzia, zwane skalami obserwacyjnymi. Powinny one zostać wypełnione przez osoby, które dobrze znają dziecko - rodzice, rodzeństwo, terapeuci czy nauczyciele. Do najpopularniejszych należą wymienione poniżej.

1. Childhood Autism Rating Scale - CARS (Skala Oceny Autyzmu Dziecięcego) autorstwa Schoplera, Reichlera, Renner. Jest ona 15 - punktową skalą behawioralną, służącą do oceny zachowania dzieci od urodzenia do szesnastego roku życia, przy czym jej użyteczność jest największa w przypadku dzieci powyżej drugiego roku życia. Wykorzystuje się ją w celach diagnostycznych, jak również do planowania oddziaływań terapeutycznych oraz oceny ich skuteczności. W obrębie każdego z 15 obszarów diagnosta dokonuje oceny zachowania dziecka na 4-stopniowej skali, określając stopień ciężkości zaburzeń [24]. Wynik ogólny daje informacje dotyczące stopnia autyzmu w kategoriach: brak autyzmu, lekki/umiarkowany lub autyzm o znacznym natężeniu [6].

2. Autism Behaviour Checklist - ABC [17]. Stosowany jest dla osób w wieku od 18 miesięcy do 35 lat. Składa się z pięciu wymiarów: wrażenia sensoryczne, relacje z innymi, wykorzystanie ciała i przedmiotów, język oraz zachowania społeczne, które obejmują 57 przykładowych zachowań (Pisula, 2005).

3. Autism Diagnostic Observation Schedule - ADOS [19]. Osoba badająca tym narzędziem musi mieć spore doświadczenie $\mathrm{w}$ pracy $\mathrm{z}$ autystycznymi dziećmi, gdyż narzędzie to składa się z pewnej liczby sytuacji eksperymentalnych, w których obserwator jest jednocześnie uczestnikiem interakcji z badanym (Pisula, 2005).

4. Checklist for Autism Children -CLAC [21]. Nie zostały określone przez autorów ramy 
wiekowe, w jakim narzędzie można stosować. Oceny funkcjonowania dziecka w obrębie 11 kategorii zachowań (m.in. jedzenie, sen, zabawa, relacje interpersonalne, komunikacja, autonomia i ekspresja emocjonalna) dokonują jego rodzice [24]. Zawiera on 28 pozycji, które opisują zachowanie dziecka bądź występowanie u niego określonych cech osobowości. Kwestionariusz pozwala również na analizę takich form zachowania jak: agresja, okazywanie złości, radości, a także umożliwia ocenę rozwoju percepcji [37].

5. Gilliam Autism Rating - GARS [12]. Skala zbudowana jest w oparciu o kryteria diagnostyczne zawarte w DSM-IV-TR i służy do diagnozy autyzmu u osób z poważnymi problemami w zachowaniu w wieku od 3 do 22 lat. Skala ta składa się z 42 pozycji wchodzących w skład trzech obszarów tematycznych (tj. zachowania stereotypowe, komunikacja, interakcje społeczne) i 14 pozycji, które dotyczą rozwoju dziecka od urodzenia do 3 roku życia. Osoba bliska dziecku, która wypełnia tę skalę ocenia częstość występowania wymienionych zachowań, przyznając od 0 (nigdy nie widziała danego zachowania) do 3 (widziała dane zachowanie 5-6 razy w ciągu każdych 6 godzin). Jej wypełnienia może się podjąć każda osoba, która posiada stały i bezpośredni kontakt z autystyczną osobą. Ogólna ocena pozwala określić współczynnik autyzmu (autism quotient - AQ). Nadal prowadzone są badania nad określeniem trafności tej skali, a z dotychczasowych badań wynika, że popełnienie błędu fałszywego wnioskowania (niewykrycia autyzmu mimo jego występowania) jest w wypadku tej skali bardziej prawdopodobne niż sytuacja odwrotna - przypisanie autyzmu dziecku zdrowemu.

PER-R - Psychoeducational Profile Revised (Profil Psychoedukacyjny) E. Schoplera, $\underline{\text { R. Reichlera, A. Bashford }}$

Profil Psychoedukacyjnym (PEP-R) [29, 30], stanowi jeden z elementów pakietu podręczników (Techniki nauczania dla rodziców i profesjonalistów, 1995; Ćwiczenia edukacyjne dla dzieci autystycznych, 1994) serii „Zindywidualizowana ocena i terapia dzieci autystycznych oraz dzieci z zaburzeniami rozwoju" (Division Treatment and Education of Autistic and Related Communication Handicapeed Children - TEACCH).

PEP-R przeznaczony jest do badania dzieci w wieku od sześciu miesięcy do siedmiu lat. Główna zaletą PEP-R jest to, że pozwala na opis możliwości dziecka w dwóch skalach: rozwoju, która zawiera 131 zadań i zachowań zawierającej 43 zadania. Elementy Skali Rozwoju podzielone są na siedem sfer rozwoju: umiejętność naśladowania, percepcja, motoryka mała, motoryka duża, koordynacja wzrokowo-ruchowa, czynności poznawcze, komunikacja i mowa czynna.

Wszystkie zadania Skali Rozwoju oceniane są w czasie wykonania testu, a system oceniania zadań składa się z trzech stopniu:

$>$ zaliczone - ocenę (zal.) otrzymuje zadanie, które dziecko potrafi samodzielnie i poprawnie wykonać,

$>$ obiecujące - ocenę obiecującą (ob.) otrzymuje takie wykonanie zadania, które wskazuje, że dziecko częściowo rozumie, jak należy je wykonać, ale nie potrafi zakończyć go pomyślnie, lub badający musi kilkakrotnie demonstrować albo uczyć wykonanie zadania,

$>$ nie zaliczone - ocenę (n. zal.) otrzymuje zadanie, którego dziecko nie jest w stanie zrobić lub nawet nie podejmuje próby jego zrobienia, pomimo kilkakrotnego demonstrowania.

Skala Zachowań PEP-R zawiera zadania podzielne na cztery części: 1. nawiązywanie kontaktów i reakcje emocjonalne, 2. zabawa i zainteresowanie przedmiotami, 3. reakcje na bodźce, 4. mowa. Konkretne zachowanie może być ocenione pozytywnie jako „odpowiednie” lub negatywnie jako „nieodpowiednie”. Jeśli zachowanie jest ewidentnie niewłaściwe, to zostaje ocenione w dwojaki sposób: „umiarkowanie nieodpowiednie” (um.) - gdy zachowanie 
dziecka jest nieco gorsze od zachowania normalnego, lub „W znacznym stopniu nieodpowiednie" (zn.) - gdy nasilenie, jakość i częstość występowania zachowania zdecydowanie różni się od normalnego i które jest jednoznacznie nietypowe.

Profil Psychoedukacyjny (PEP-R) prezentuje rozwojową koncepcję oceny dzieci z autyzmem oraz dzieci z zaburzeniami rozwoju, a wyniki uzyskane $\mathrm{w}$ teście wykorzystywane są do ułożenia Indywidualnych Programów Nauczania. Wyniki Skali Rozwoju mają odniesienie do kryterium normy rozwojowej, dzięki nim można określić wiek rozwojowy badanego dziecka w zakresie badanych umiejętności. Natomiast Skala Zachowań ma dopomóc $\mathrm{w}$ postawieniu diagnozy. Dostarcza ona informacji nie tylko na temat stopnia zaburzeń w zachowaniu dziecka, ale również określa poszczególne dziedziny, w jakich się one pojawiają [30].

Po przeprowadzeniu badania, wyniki są nanoszone na wykres profilu, co pozwala $\mathrm{w}$ przystępny sposób zobrazować charakter deficytów rozwoju z uwzględnieniem szczególnych jego właściwości, takich jak dysharmonia. Zadania ocenione jako „obiecujące”, dotyczą tych umiejętności dziecka, które leżą w sferze jego najbliższego rozwoju i dolicza się je do podstawowego wyniku, co pozwala przewidywać rozwój dziecka w najbliższym czasie, po wprowadzeniu określonych, zindywidualizowanych działań terapeutycznych (Pisula, 2005).

$>$ Narzędzie przesiewowe

1. The Checklist for Autism in Toddlers - CHAT, Kwestionariusz Autyzmu w Okresie

Poniemowlęcym Barona-Cohena, Allen, Gillberga. Przeznaczony jest do badania dzieci w wieku 18 miesięcy i składa się z dwóch części: wywiadu z rodzicem ( 9 pozycji) i części obserwacyjno-eksperymentalnej (5 pozycji) skierowanej do diagnosty, w której dziecko poddawane jest praktycznym zadaniom związanym z zagadnieniem zabawy symbolicznej i dzielenia wspólnego pola uwagi. Tego typu narzędzia są najbardziej pomocne w wyszukiwaniu dzieci z umiarkowanym bądź głębszym natężeniem autyzmu, dlatego też zaleca się aby posługiwali się nimi specjaliści mający duże doświadczenie w ocenie rozwoju małych dzieci $[6,15,32]$.

2. Modified Checklist for Autism in Toddlers - M-CHAT [28]. Modyfikacja

wcześniejszej metody CHAT polegała przede wszystkim na zrezygnowaniu z obserwacji prowadzonej przez diagnostę (np. lekarza) i skupieniu się na pozyskiwaniu informacji od rodziców dziecka. M-CHAT składa się z 23 pozycji, w tym 9 przeniesionych z CHAT. Dodane itemy dotyczą m.in. preferowanych przez dziecko form aktywności, jego zainteresowań społecznych, kontaktu wzrokowego, wrażliwości na bodźce, rozwoju motorycznego oraz rozumienia mowy

3. Screening Tool for Autism in Two-Yers-Olds - STAT autorstwa Stone i Opal [33],

przeznaczone jest do wykrywania autyzmu u dzieci w wieku 24-35 miesięcy, a także do różnicowania autyzmu i innych zaburzeń rozwoju. W trakcie stosowania tego narzędzia obserwuje się dziecko w 12 sytuacjach, kiedy to diagnosta próbuje nawiązać z nim kontakt inicjując różnego rodzaju sytuacje, np. badający porusza samochodzikiem i prosi, aby dziecko zrobiło podobnie; badający dmucha balon i podrzuca go, jednocześnie obserwując czy dziecko będzie śledziło balon wzrokiem [24].

4. Screen for Social Interaction - SSI [11], przeznaczony jest do badania dzieci w wieku od 6 miesięcy do 5 lat. Dzięki niemu możliwe jest określenie problemów w kontaktach społecznych u dzieci z różnymi typami zaburzeń, nie tylko należących do autystycznego spektrum. SSI składa się z 54 pytań skierowanych do rodziców (lub wychowawców). Poszczególne pozycje dotyczą różnych sytuacji społecznych (np. Czy kiedy mówisz do dziecka, ono patrzy na Ciebie, uśmiecha się do Ciebie?), dzięki którym zbierane są informacje na temat zdolności dziecka do uczestniczenia w naprzemiennych interakcjach z innymi ludźmi. Rodzic lub opiekun dokonuje oceny poszczególnych sytuacji na czterostopniowej skali - od ,prawie nigdy” do ,prawie zawsze”. Konstrukcja narzędzia 
oparta jest na perspektywie rozwojowej, gdyż każde kolejne pytanie odnosi się do coraz wyższego poziomu rozwoju społecznego dziecka [24].

5. Autistic Spectrum Quotient - ASQ [3], cechuje się dużą wrażliwością na

występowanie symptomów autystycznych u badanych dzieci. Dostępne są dwie jego wersje: dla dzieci w wieku 4-6 lat oraz powyżej 6 roku życia. 40 pozycji kwestionariusza zleca się wypełnienie rodzicom. Budowa narzędzia jest wzorowana na opisanym wyżej ADI-R, a poszczególne itemy dotyczą trzech obszarów tematycznych, zgodnych $\mathrm{z}$ kryteriami diagnostycznymi autyzmu, tj. naprzemienne interakcje społeczne, komunikacja oraz sztywne, powtarzalne wzorce zachowania [24].

6. Diagnostyczna Lista Kontrolna (E-2) Rimlanda. Jest to metoda screeningowa umożliwiająca identyfikacje dzieci $\mathrm{z}$ autyzmem oraz wyróżnienie typów autyzmu. E-2 zawiera 109 pytań skierowanych do rodziców i dotyczących m.in. relacji społecznych, mowy, rozwoju poznawczego, motoryki, percepcji dziecka. Wyniki uzyskiwane są w przedziale punktowym od -45 do +45 : wynik powyżej +20 pkt. - wskazuje na klasyczny autyzm wczesnodziecięcy (tzw. syndrom Kannera); wynik od -15 do +19 pkt. - wskazuje na autyzm; wynik -16 pkt. lub niższy - dzieci uzyskujące ten przedział punktowy, nie są diagnozowane jako autystyczne, lecz jako dzieci $\mathrm{z}$ cechami autyzmu lub dzieci upośledzone umysłowo $\mathrm{z}$ cechami autyzmu. Im wynik jest niższy tym mniejsze prawdopodobieństwo, że u dziecka zdiagnozowany zostanie autyzm. Diagnoza przy pomocy E-2 przed 36 miesiącem życia jest raczej mało przydatna. Wskazana jest powyżej 3 roku życia. Suplementem do E-2 jest lista E-3, która zawiera około 200 pytań adresowanych do rodziców i dotyczących m.in. okresu ciąży, szczepień, alergii, stosowanych środków farmakologicznych [6].

Wyżej opisane narzędzia badawcze nie stanowią wystarczającej podstawy do rozpoznania autyzmu, jedynie mogą stanowić początek procesu diagnostycznego [24].

$>$ Southern California Sensory Integration Tests - SCSIT (Południowo Kalifornijskie Testy Integracji Sensorycznej) Ayres.

Zostały opracowane w celu dokładnej diagnozy zaburzeń sensorycznych, które według Ayres są przyczyną określonych zaburzeń procesu uczenia. Składają się z 17 podtestów: I. Testy postrzegania wzrokowego: 1) wyobrażenie przestrzenne, 2) postrzeganie figury na tle, 3) usytuowanie przestrzenne; II. Testy postrzegania wzrokowo-motorycznego: 4) odtwarzanie wzorca, 5) dokładność ruchowa; III. Testy postrzegania dotykowo-kinestetycznego: 6) kinestezja, 7) manualne postrzeganie kształtu, 8) identyfikacja palców, 9) grafestezja, 10) lokalizacja bodźców dotykowych, 11) postrzeganie podwójnych bodźców dotykowych; IV. Testy schematu ciała: 12) naśladowanie postawy ciała, 13) przekraczanie środkowej linii ciała, 14) koordynacja motoryczna obu stron ciała, 15) rozróżnianie strony lewej i prawej, 16) utrzymanie równowagi $\mathrm{z}$ otwartymi oczami, 17) utrzymanie równowagi $\mathrm{z}$ zamkniętymi oczami. Test przeznaczony jest do badania dzieci w wieku od 5 do 8 lat [6].

Obserwacja kliniczna ukierunkowana na diagnozowanie zaburzeń sensorycznych.

Testy autorstwa Ayres trudno zastosować u dzieci autystycznych, dlatego też wielu terapeutów opierając się na SCSIT tworzy własne, alternatywne metody. Przykładem jest Indywidualny Profil Zmysłów (ISP). Podstawę jego opracowania stanowi dokładna obserwacja dziecka w trakcie swobodnej zabawy, podczas której wykonuje ono polecenia diagnosty. Oceny w IPS oparte są na subiektywnej ocenie terapeuty na skali: 1-oznacza znacznie obniżoną wrażliwość, 3-normę, 5-znaczną nadwrażliwość, 2 i 4-to oceny pośrednie. Ocena dokonywana jest $\mathrm{w}$ kilku sferach tj. równowaga, propriorecepcja, system dotykowokinestetyczny, system wzrokowy, słuchowy, smak, zapach, odczuwanie temperatury i bólu. Dzikowski - terapeuta W zakresie integracji sensorycznej dzieci autystycznych zaprezentował przykład obserwacji klinicznych, powstałych w oparciu o metodę Ayres, które stanowią uzupełnienie Indywidualnego Profilu Zmysłów: postrzeganie dotykowo- 
kinestetyczne (odtwarzanie figur rysowanych na skórze, lokalizacja bodźców dotykowych, postrzeganie przedmiotów dotykiem bez udziału wzroku, naśladowania pozycji ciała); pierwotne reakcje odruchowe (asymetryczny odruch szyjny, toniczny odruch przedsionkowy); planowanie ruchu (obserwacja, jak dziecko wykonuje złożone ruchy, np. przechodzi przez przeszkody); reakcje podstawne i równowagi (stanie na jednej nodze, chodzenie na palcach, piętach, podskakiwanie na jednej nodze); integracja bilateralna (np. dziecko rysuje jednocześnie dwa okręgi obiema rękoma, podskakuje na obu nogach); motoryka palców i dłoni (np. diadochokineza); motoryka oczu (śledzenie poruszających się przedmiotów, oczność); motoryka języka i ust (np. poruszanie językiem pomiędzy kącikami ust, gwizdanie); współruchy towarzyszace (czy np. podczas liczenia z zamkniętymi oczami i wyciągniętymi rękami, w obrębie dłoni i palców występują współruchy) [6].

Przed zaplanowaniem terapii sensorycznej dzieci autystycznych wartym zastosowania może być test Ayres, badający oczopląs porotacyjny. SCPRNT - Southern California Postrotary Nystagmus Test jest próbą służącą ocenie funkcjonowania zmysłu równowagi u dziecka, której dokonuje się w obecności lekarza. Na niedowrażliwość zmysłu równowagi wskazuje brak lub skrócenie oczopląsu porotacyjnego. W takim wypadu, podczas terapii należy stosować ćwiczenia, które wymagają ułożenia głowy w zakresie różnych kierunków. Natomiast na nadmierną wrażliwość zmysłu równowagi wskazuje wydłużony oczopląs porotacyjny, dlatego też terapię należy rozpocząć od wolnych ruchów liniowych [6].

Proces diagnozowania autyzmu obejmuje nie tylko stwierdzenie w zachowaniu dziecka określonych trudności, ale również badanie medyczne, które w głównej mierze ma na celu wykluczenie innych przyczyn problemów doświadczanych przez dziecko i ocenę stanu jego zdrowia. Część medyczna badania obejmuje ocenę stanu zdrowia somatycznego, słuchu, wzroku oraz badanie neurologiczne. Do zalecanych badań należą:

- testy genetyczne - badania DNA w celu stwierdzenia ewentualnych nieprawidłowości genetycznych powodujących zaburzenie rozwoju dziecka, jak np. zespół kruchego chromosomu $\mathrm{X}$ oraz inne, $\mathrm{w}$ przypadku których stwierdza się u dziecka występowanie zachowań o cechach autystycznych. Należy zaznaczyć, że nie ma testu genetycznego, który wskazałby obecność genu autyzmu,

- badania metaboliczne - laboratoryjne badania krwi, moczu i kału, które moga świadczyć o nieprawidłowościach w przebiegu procesów metabolicznych innych zakłóceniach zdrowotnych,

- badanie słuchu - prowadzone w kierunku wykrycia problemu dziecka ze słuchem, który mógłby być odpowiedzialny za jego trudności w rozwoju mowy,

- badanie budowy i funkcjonowania mózgu: elektroencefalografia (EEG), rezonans magnetyczny (MRI), tomografia komputerowa [25].

\section{Wybrane formy terapii i rehabilitacji osób $\mathrm{z}$ autyzmem}

Terapia autyzmu jest obecnie terapią syndromologiczną (objawowa), a nie przyczynową, z uwagi na brak metod leczenia zaburzeń o charakterze neurorozwojowym. Podstawowym celem terapii jest poprawa funkcjonowania behawioralnego dziecka, jego funkcji poznawczych, relacji $\mathrm{z}$ otoczeniem oraz pomoc rodzinie dziecka dotkniętego autyzmem. Terapię zaburzeń autystycznych można podzielić na metody farmakologiczne (przeznaczone dla lekarzy psychiatrów i neurologów) i metody interwencji psychosocjoterapeutycznej [36].

Do metod określanych jako psychosocjoterpeutyczne można zaliczyć m.in. oddziaływania pedagogiczne, terapię behawioralną czy systemową. Farmakoterapia natomiast zajmuje się leczeniem objawów zaburzonego zachowania u autysty. Istnieją w Polsce również metody niekonwencjonalne terapii autyzmu, wśród których można wymienić akupunkturę, terapię czaszkowo-krzyżową, prowadzenie dziecka na diecie bezglutenowej i bezkazeinowej (bez wskazań medycznych), erydykację grzyba Candida albicans [36]. 
Terapię dziecka autystycznego można prowadzić na kilka sposobów, przy szczególnym uwzględnieniu indywidualnych predyspozycji małego człowieka do terapeutycznej pracy. W zależności od tego, na jakim etapie rozwoju się on znajduje, należy wziąć pod uwagę jego ,wycofanie” i podjąć odpowiednie formy i techniki pracy. W tym paragrafie zostanie przedstawiona charakterystyka kilku rodzajów terapii, które stosuje się w pracy z autystycznych dzieckiem [37]. Krótko omówione zostaną te metody, które cieszą się największą popularnością:

Terapia wymuszonego kontaktu - holding

Została opracowana przez Welch w USA. Zakłada się w niej, że autyzm spowodowany jest przez silny lęk, którzy zaburza równowagę emocjonalną dziecka i w efekcie prowadzi do wycofania się go z kontaktów społecznych. Natomiast lęk, według autorki, jest konsekwencja braku więzi między matką i niemowlęciem, a sposobem na jej odbudowanie jest kontakt fizyczny [26]. W terapii holding zachęca się rodziców - w szczególności matkę, aby przytulali swoje dziecko przez dłuższy czas, mimo jego protestów i sprzeciwów. Podczas takiego wymuszonego przytrzymywania (holdingu) dziecko w konsekwencji przełamuje opór i w opinii rodziców, zaczyna interesować się twarzą matki, czy ojca, poprawiając przy tym kontakt wzrokowy z rodzicami, jak również wpływa na poprawę relacji społecznych i umiejętności komunikacyjnych między nimi, a dzieckiem. Każda sesja składa się z trzech etapów: konfrontacji, odrzucenia i rozwiązania. W opinii obserwatorów tego rodzaju zabiegów stosowanych na dziecku istnieją wątpliwości, czy intensywny kontakt fizyczny i społeczny może spowodować zmiany w funkcjonowaniu dziecka. Zwolennicy tej terapii twierdzą, że przynosi ona korzyści także rodzicom, którzy deklarują powstanie uczucia bliższego kontaktu fizycznego ze swoim dzieckiem w efekcie terapii i większość tych zmian jest według nich ,warta zachodu”. Jednakże, jak dotąd, nie ma obiektywnych dowodów na to, że terapia holding leczy autyzm, a jej wartość bywa kwestionowana [4].

Program TEACCH

Został on opracowany przez Schoplera i jego współpracowników [29, 30]. Skrót TEACCH oznacza leczenie $\mathrm{i}$ uczenie dzieci autystycznych $\mathrm{i}$ dzieci $\mathrm{z}$ zaburzeniami komunikacyjnymi. Głównym jego celem jest pomoc dzieciom autystycznym w osiągnięciu jak największej autonomii $\mathrm{w}$ przyszłości. Uczestnictwo $\mathrm{w}$ zajęciach pomaga dzieciom zrozumieć i poznać świat wokół nich, rozwinąć umiejętności komunikacyjne oraz nauczyć się tworzenia prawidłowych relacji z rówieśnikami i innymi ludzi. Terapia TEACCH zawiera opracowane indywidualnie programy interwencyjne oraz konsultacje prowadzone w szkole. Przed rozpoczęciem zajęć właściwych dokonuje się oceny zdolności edukacyjnych za pomocą Profilu Psychoedukacyjnego (Psycho-Educational Profile-PEP), w celu określenia w jakich dziedzinach dziecko posiada wystarczające umiejętności, $w$ jakich ich nie posiada oraz jakie umiejętności dziecka aktualnie się rozwijają. Wyniki profilu bierze się pod uwagę opracowując program nauczania dla danego dziecka [27]. Program TEACCH obejmuje również swoim zasięgiem pracę $\mathrm{z}$ rodzicami poprzez adresowane do nich szkolenia, poradnictwo lub/i pomoc w tworzeniu grup wsparcia [4].

Metoda Dobrego Startu

Metoda powstała w oparciu o francuską metodę Le Bon Depart. Na grunt Polski została przeniesiona przez Bogdanowicz po koniec lat 60-tych. Metoda ta jest terapią psychomotoryczną, czyli postrzega związki pomiędzy rozwojem psychicznym, a ruchowym. Aktywizowanie jednej ze sfer, wpływa korzystnie na sferę drugą. W terapii chodzi o usprawnienie i harmonizowanie współdziałania motoryki i psychiki. Prowadzone przez Bogdanowicz badania dowiodły, że metoda ta: usprawnia funkcje percepcyjne i motoryczne oraz ich współdziałanie; utrwala lateralizację; uczy orientacji w schemacie ciała i przestrzeni; rozwija mowę; oddziałuje na procesy emocjonalne; uczy zachowań społecznych. Metoda Dobrego Startu jest jedną z możliwych form pracy z dziećmi autystycznymi. Jest pomocna w 
nauce nawiązywania przez nie kontaktów z innymi osobami i przyczynia się do poprawy funkcjonowania dziecka $\mathrm{w}$ wyżej wymienionych sferach rozwoju. $\mathrm{Z}$ dziećmi pracuje się dość długo, aby były zauważalne efekty tych oddziaływań. Jednak metoda ta nie ma w sobie elementów, które mogłyby w jakikolwiek sposób zaszkodzić dzieciom [37].

Terapia zaburzeń sensorycznych

Należy ją traktować przede wszystkim jako terapię podstawową, która ma na celu złagodzenie określonych zaburzeń $\mathrm{w}$ przetwarzaniu danych percepcyjnych. Celem takiej terapii jest oddziaływanie na zaburzone sfery, a nie edukacja dziecka. Dziecko jest niejako „samo swoim terapeutą", musi być aktywne i właściwie wybierać z repertuaru oddziaływań zaproponowanych przez terapeutę to, co sprawia mu przyjemność i czego w danym momencie potrzebuje. Terapeuta jest narzędziem w rękach dziecka i musi na początku sam doświadczyć wszystkiego, co chce zaproponować dziecku. Terapeuta powinien być wrażliwy na informacje płynące od dziecka w zakresie jego reakcji na wysyłany do niego bodziec, gdyż zadaniem Delacato - bodziec kierowany do dziecka powinien mieć taką częstotliwość, natężenie i czas trwania, aby mógł być spokojnie odebrany przez dziecko. Celem wszystkich techniki stosowanych w terapii zaburzeń sensorycznych, jest wyrobienie tolerancji u dziecka na bodźce pochodzące ze świata zewnętrznego i kontrolowania ich przez terapeutę [6].

\section{Metoda ruchu rozwijajacego W.Sherborne}

Głównym jej założeniem jest posługiwanie się ruchem jako narzędziem we wspomaganiu rozwoju psychoruchowego $\mathrm{i}$ w terapii zaburzeń rozwoju. Terapia ta jest również swego rodzaju niewerbalnym treningiem interpersonalnym, który początkowo przeznaczony był dla dzieci upośledzonych w stopniu głębokim. Obecnie stosowana jest również w pracy z dorosłymi [6]. Podstawowe założenia tej metody to rozwijanie przez ruch: świadomości własnego ciała i usprawniania ruchowego; świadomości przestrzeni i działania $\mathrm{W}$ niej oraz dzielenia przestrzeni $\mathrm{z}$ innymi dziećmi i nawiązywanie $\mathrm{z}$ nimi bliskiego kontaktu [7]. W trakcie zajęć dzieci wyrabiają w sobie poczucie bezpieczeństwa, zaufania wobec innych, odpowiedzialności. Zajęcia mają pomóc dziecku w poznaniu samego siebie, w zdobyciu do siebie zaufania, poznaniu innych i nauczeniu się ufania im. Aby tego dokonać dzieci mają do dyspozycji tylko ruch i bliski kontakt z drugim człowiekiem.

Metoda Opcji

Jej twórcami jest małżeństwo Kauffman, którzy „wyprowadzili” z autyzmu swojego syna - uznanego przez specjalistów za głęboko zaburzonego. Terapeuta pracuje intensywnie przez 24 godziny nad ustanowieniem więzi z dzieckiem. Rodzice natomiast uczestniczą w specjalnie do nich przygotowanych programach rodzinnych [4]. Istotnym zadaniem terapeutów jest aktywne uczestniczenie w tym, co sprawia dziecku przyjemność, nawet w jego rytualistycznych i obsesyjnych zachowaniach. Dzięki takiej formie oddziaływań, pozyskują oni zaufanie dziecka, które wykorzystują do stopniowego otwierania go na nowe doświadczenia. Podstawową formą pracy są intensywne interakcje jeden na jeden - terapeuty z dzieckiem. Celem opcyjnego ,terapeuty” jest stworzenie w pokoju dziecka bezpiecznego i wystarczająco atrakcyjnego dla niego azylu, aby przedkładało ono zainteresowanie nim nad swój nieprzewidywalny, wewnętrzny świat [34]. Efekty tej terapii trudno jest jednoznacznie ocenić, gdyż brak jest udokumentowanych danych co do jej rezultatów i skuteczności [26].

Terapia poprzez muzyke

Muzykoterapia działa uspokajająco na wiele dzieci z autyzmem. Służy jako zachęta do komunikowania się, jak również do wyłaniania przeciętnych, a niejednokrotnie nadzwyczajnych talentów muzycznych u autystycznych dzieci [4]. Terapia przez muzykę może być wykorzystywana jako środek sprzyjający wypracowaniu umiejętności społecznych, przezwyciężeniu lęku czy nieprawidłowości integracji sensorycznej. Wykorzystując muzykę w terapii należy pamiętać o indywidualnych predyspozycjach autystycznych dzieci w tym zakresie, ponieważ jedno dziecko może pozytywie zareagować na stosowane techniki 
muzykoterapeutyczne lub wybrane utwory muzyczna, a u innego mogą one wywołać reakcje negatywne, czy wręcz niebezpieczne [16].

Farmakoterapia

Właściwe korzystanie z leków może być częścią kompleksowej terapii autyzmu, ale nie może zastąpić odpowiednich programów edukacyjnych i społecznych. Lekarstwa są skuteczne w redukowaniu lęków, ale nie zastąpią pracy terapeutycznej człowieka $\mathrm{z}$ człowiekiem [13]. W leczeniu autyzmu wykorzystywane powinny być wszelkie medyczne strategie, skuteczne w przypadku różnorodnych nieprawidłowości stwierdzonych u osób z autyzmem, m.in. nietolerancji glutenu i kazeiny, defektów immunologicznych, podatności na infekcje różnego rodzaju, choroby odpasożytnicze, zaburzenia metabolizmu czy zatruć chemicznych [26].

Dane $\mathrm{z}$ badań wykazują, że leki antydepresyjne, tj. klomipramina (anafril) i fluoksentyna (prozac) dość często przynoszą dobre rezultaty u osób autystycznych w postaci zmniejszenia zaburzeń obsesyjno-kompulsywnych i gonitwy myśli. Natomiast anafranil podobny w swym działaniu do norpraminu i tofranilu, podnosi poziom serotoniny w mózgu, substancji, która w sposób kojący działa na układ nerwowy. O stosowaniu leków w autyzmie wielu rzeczy jeszcze nie wiadomo, a z doniesień rodziców wynika, że występuje wiele poważnych działań niepożądanych, gdy dawka leku zostaje zwiększona z powodu nawrotu lęków czy zaburzeń zachowania. Leki w autyzmie stosować należy ze szczególną rozwagą, gdyż np. jeśli u autystycznej osoby występują jakieś nieprawidłowości w zapisie EEG, niebezpieczne może być zażywanie tych leków przeciwdepresyjnych, które mogą spowodować napady epileptyczne. U takich osób skuteczne okazują się m.in. buspiron (spamilan) - lek uspokajający, klonidyna (catapres) czy beta-blokery (propranolol) - leki na nadciśnienie. Osoby autystyczne, zanim zaczną przyjmować jakikolwiek przypisany im lek, musza przejść konsultację lekarską u specjalisty znającego się na farmakoterapii w autyzmie [13]. Zebrane dotychczas dane są obiecujące, jednakże nie wprowadziły one rewolucji w leczeniu tego zaburzenia.

Terapie behawioralne

Podstawowym ich celem jest kształtowanie zachowań adaptacyjnych (np. trening czystości, trening samoobsługi) lub redukcja zachowań trudnych (nieodpowiednich) - np. plucia, autoagresji. W terapii behawioralnej analizuje się przyczyny i konsekwencje zachowania, a następnie wprowadza się odpowiedni program behawioralny. Jego celem jest odnalezienie czynników nagradzających lub zachęcających do prawidłowego zachowania oraz powodujących wyeliminowanie nieprawidłowych - zachowań destrukcyjnych. Współczesna terapia behawioralna jest daleka od karania dziecka, natomiast stara się wyeliminować złe zachowania poprzez usuwanie czynników - sytuacji, które do nich prowadzą i zastępować je prawidłowymi zachowaniami - umiejętnościami. Terapię behawioralną stosuje się $\mathrm{w}$ zmniejszeniu takich problemów jak: samookaleczenie, nadruchliwość, agresja, ataki złości. Jest pomocna w zakresie rozwijania umiejętności samoobsługowych czy edukacyjnych dziecka [4].

\section{Podsumowanie}

Podsumowanie niech stanowią słowa Frith: „Czy nasz stosunek do autyzmu się zmieni, gdy już poznamy jego przyczyny i mechanizmy z nim związane? Możliwe. Tak stało się w wypadku niektórych innych chorób. Rodzice dzieci z zespołem Downa wiedzą teraz, że jego przyczyną jest wada określonego chromosomu. Godzą się więc z faktem, że zespół Downa trwa całe życie, i są mniej podatni na sugestie różnych szarlatanów zachwalających swoje lekarstwa" [10]. 
W aspekcie diagnozy autyzmu należy podkreślić, że wymaga ona powołania zespołu specjalistów, w skład którego wchodzi najczęściej psychiatra dziecięcy, neurolog, psycholog oraz lekarz pediatra.

Zaprezentowany, krótki opis wybranych terapii daje wyraz nieprzerwanej inspiracji klinicystów starających się pokonać, pod wpływem różnego rodzaju oddziaływań skierowanych na dziecko i jego rodziców, główne symptomy autyzmu. Rodzice stojący przed wyborem specjalisty pracującego według wybranej metody powinni w tym względzie zachować ostrożność, jak również wobec twierdzeń o możliwość wyleczenia ich dziecka.

\section{Piśmiennictwo}

1. Amaral D G, Schumann C M, Wu Nordahl Ch. Neuroanatomy of autism. Trends in Neurosciences. 2008; 31:137-145.

2. Bailey A, Palferman S, Heavey L, Le Couteur A. Autism: the phenotype in relatives. Journal of Autism and Developmental Disorders.1998; 28:369-392.

3. Baron-Cohen S. et al. The Autism-Spectrum Quotient (AQ): Evidence from Asperger Syndrome/High-Functioning Autism, Males and Females. Scientists and Mathematicians. 2001; 31:5-17.

4. Baron-Cohen S, Bolton P, Autyzm. Fakty. (przekł. E. Wiekiera), Krajowe Towarzystwo Autyzm, Kraków 1999.

5. Beversdorf D Q, Manning S E, Hillier A, Anderson S L, Nordgren R E, Walters S E, Nagaraja H N, Cooley W C, Gaelic S E, Bauman M L. Timing of prenatal stressors and autism. Journal of Autism and Developmental Disorders. 2005; 35:471-478.

6. Bobkowicz-Lewartowska L, Autyzm dziecięcy. Zagadnienia diagnozy i terapii, Oficyna Wydawnicza „Impuls”, Kraków 2000.

7. Bogdanowicz M, Kisiel B, Przasnyska M, Metoda Weroniki Sherborne $w$ terapii $i$ wspomaganiu rozwoju dziecka, WSiP, Warszawa 1992.

8. Elder L M, Dawson G, Toth K, Fein D, Munson J. Head circumference as an early predictor of autism symptoms in younger siblings of children with autism spectrum disorder. Journal of Autism and Developmental Disorders. 2008; 38:1104-1111.

9. Folstein S E, Bisson E, Santangelo S L, Piven J. Finding specific genes the cause autism: a combination of approaches will be needed to maximize power. Journal of Autism and Developmental Disorders. 1998; 28:439-455.

10. Frith U, Autyzm. Wyjaśnienie tajemnicy. (przekł. M. Hernik, G. Krajewski), GWP, Gdańsk 2008.

11. Ghuman J K, Leone S L, Lecavalier L, Landa R J. The screen for social interaction (SSI): A screening measure for autism spectrum disorders in preschoolers. Research in Developmental Disabilities. 2011; 32:2519-2529.

12. Gilliam J E, Gilliam Autism Rating Scale, TX: ProEd, Austin 1995.

13. Grandin T, Myślenie obrazami oraz inne relacje $z$ życia $z$ autyzmem, Fraszka Edukacyjna we współpracy z Fundacją SYNAPSIS, Warszawa 2006.

14. Jagielska G, Etiologia zaburzeń autystycznych, [w:] J. Komender, G. Jagielska, A. Bryńska, Autyzm i zespół Aspergera, Wydawnictwo Lekarskie PZWL, Warszawa 2009, s. 17-31.

15. John R. A review of recent reports on autism: 1000 studies published in 2007. Hughes Epilepsy \& Behavior. 2008; 13: 425-437.

16. Jutrzyna E, Dziecko autystyczne w kręgu muzyki, [w:] (red.) J. J. Błeszyński, Terapie wspomagające rozwój osób z autyzmem, Oficyna Wydawnicza „Impuls”, Kraków 2005, s. 57-82.

17. Krug D, Arick J, Almond P. Behavior Checklist for Identifying Severely Handicapped Individuals with High Levels of Autistic Behavior. Journal of Child Psychology and Psychiatry. 1980; 21:221-229. 
18. Landa R, Garrett-Mayer E. Development in infants with autism spectrum disorders: A prospective study. Journal of Child Psychology and Psychiatry. 2006; 47:629-638.

19. Lord C, Rutter M, DiLavore P, Risi S, Autism diagnostic observation schedule (ADOS), Western Psychological Services, Los Angeles 1999.

20. Maciarz A, Trudne dzieciństwo i rodzicielstwo, Wydawnictwo Akademickie Żak, Warszawa 2009.

21. Makita K, Umezu K. An objective evaluation technique for autistic children: An introduction of CLAC scheme. Acta Paedopsychiatrica. 1973; 39:237-53.

22. Minshew N J, Sweeney J A, Bauman M L, Webb S J, Neurologic aspects of autism. [w:] (red.) F. R. Volkmar, R. Paul, A. Klin, D. J. Cohen, Handbook of autism and pervasive developmental disorders, John Wiley\&Sons, Hoboken NJ 2005, s. 473-514.

23. Pisula E, Autyzm u dzieci. Diagnoza, klasyfikacja, etiologia, Wydawnictwo Naukowe PWN, Warszawa 2001.

24. Pisul E, Mate dziecko z autyzmem. Diagnoza i terapia, GWP, Gdańsk 2005.

25. Pisula E, Autyzm. Przyczyny, symptom, terapia, Wydawnictwo Harmonia, Gdańsk 2010.

26. Pisula E, Danielewicz D, Terapia i edukacja osób z autyzmem - historia i dzień dzisiejszy. [w:] (red.) D. Danielewicz, E. Pisula, Terapia i edukacja osób z autyzmem. Wybrane zagadnienia, Wydawnictwo Akademii Pedagogiki Specjalnej, Warszawa 2003, s. 9-42.

27. Randall P, Parker J, Autyzm. Jak pomóc rodzinie. (przekł. S. Pikiel), Gdańskie Wydawnictwo Psychologiczne, Gdańsk 2002.

28. Robins D L, Fein D, Barton M L, Green J. The modified checklist for autism in toddlers: An initial study investigating the early detection of autism and pervasive developmental disorders. Journal of Autism and Developmental Disorders. 2001; 31(2):131-144.

29. Schopler E, Lansing M, Waters L, Zindywidualizowana ocena i terapia dzieci autystycznych $i$ oraz dzieci z zaburzeniami rozwoju. Techniki nauczania dla rodziców $i$ profesjonalistów. (przekł. M. Bogdanowicz, B. Troszczyńska, A. Kubińska, W. Kubiński), GWP, Gdańsk 1995.

30. Schopler E, Reichler R J, Bashford A, Lansing M D, Marcus L M, Zindywidualizowana ocena $i$ terapia dzieci autystycznych $i$ oraz dzieci z zaburzeniami rozwoju. Profil Psychoedukacyjny PEP-R. (przekł. A. Witkowska), Stowarzyszenie Pomocy Osobom Autystycznym, Gdańsk 1995.

31. Schumann C M, Barnes C C, Lord C, Courchesne E. Amygdala Enlargement in Toddlers with Autism Related to Severity of Social and Communication Impairments. BIOL PSYCHIATRY. 2009; 66: 942-949.

32. Skórczyńska M, Wczesne diagnozowanie autyzmu - perspektywy i dylematy. [w:] (red.) B. Winczura, Autyzm. Na granicy zrozumienia, Oficyna Wydawnicza „Impuls”, Kraków 2009, s. 35-63.

33. Stone W L, Coonrod E E, Ousley O Y. Screening tool for autism in two-year-olds (STAT): Development and preliminary data. Journal of Autism and Developmental Disorders. 2000; 30:607-612.

34. Swenson M, Metoda Opcji: filozofia, terapia, sposób na życie - refleksje wolontariusza. [w:] (red.) E. Pisula, D. Danielewicz, Wybrane formy terapii $i$ rehabilitacji osób z autyzmem, Oficyna Wydawnicza „Impuls”, Kraków 2005, s. 153 165.

35. Turkington C, The Encyclopedia of the Brain and Brain Disorders, Second Edition, Facds On File 2002. 
36. Witusik A, Autyzm - wprowadzenie do metod terapeutycznych, doktryna terapii. [w:] (red) T. Pietras, A. Witusik, P. Gałecki, Autyzm - epidemiologia, diagnoza i terapia, Wydawnicto Continuo, Wrocław 2010, s. 171-174.

37. Zabłocki J K, Autyzm, seria: „Podstawy Pedagogiki Rewalidacyjnej”, Wydawnictwo Naukowe NOVUM, Płock 2002. 